http://dx.doi.org/10.18778/1429-3730.45.01

\author{
Ewa M. Boryczka*
}

\title{
BAZA EKONOMICZNA W PROCESIE REWITALIZACJI MIAST POPRZEMYSLOWYCH
}

\author{
ECONOMIC BASE IN URBAN REGENERATION PROCESS \\ IN POSTINDUSTRIAL CITIES
}

\begin{abstract}
Polish cities are constantly changing, and in view of the rapid socio-economic and political changes are naturally faced with many new problems. As a result of the wave of political and economic changes which took place after 1989, many Polish cities faced not only the challenge of adapt their spaces to the changing conditions and needs of the residents, but also that of adapting their competencies and skills to changing requirements and needs of the labour market.

Problems of unemployment, with their associated long-term problems of poverty and social exclusion, as well as a lack of local community engagement in public life worsened the plight of many former industrial cities. Revitalization of the regeneration processes, designed to lead portions or entire cities out of the crisis, seems to be the ideal tool to improve the situation of decaying industrial cities. This article attempts to identify the key components in the revitalization and regeneration processes available to such cities, in particular their economic bases and the opportunities offered by such processes.
\end{abstract}

Keywords: economic base theory, economic base, revitalization process, post-industrial city JEL classification: P25

\section{Wstęp}

Miasta $\mathrm{w}$ procesie globalizacji gospodarki, w tym również polskie podlegają polaryzacji, co oznacza, że obok miast szybko dostosowujących się do nowych uwarunkowań są też miasta, które nie nadążają z przekształceniami i nabierają coraz bardziej peryferyjnego charakteru. Zmiany ustroju politycznego i gospodarczego w Polsce po 1989 r. wymusiły na nich konieczność przystosowania się do nowych warunków. W szczególnie trudnej sytuacji znalazły się miasta charakteryzujące się

* Katedra Gospodarki Regionalnej i Środowiska, Uniwersytet Łódzki, e-mail: ewa.boryczka@uni.lodz.pl 
przewagą tradycyjnych gałęzi przemysłu, zwłaszcza te z jedną dominującą działalnością, niedorozwojem usług oraz brakami w infrastrukturze technicznej'. Borykają się one $\mathrm{z}$ wieloma problemami związanymi nie tylko $\mathrm{z}$ niedostosowaniem przestrzeni do zmieniających się potrzeb mieszkańców, ale także z nieodpasowaniem kompetencji i umiejętności pracowników do zmian na rynku pracy, bezrobociem, w tym długotrwałym, problemami ubóstwa, marginalizacji społecznej, a także z brakiem aktywności lokalnej społeczności w życiu publicznym. Bardzo duże bezrobocie, niedopasowanie podaży do popytu na rynku pracy skutkuje trudną sytuacją ekonomiczną mieszkańców, a także licznymi problemami społecznymi i przede wszystkim wymaga pobudzenia lokalnej gospodarki. Wiele polskich miast w związku z ich trudną, kryzysową sytuacją wymaga inicjowania i prowadzenia działań rewitalizacyjnych, w celu wyprowadzenia ze stanu kryzysowego najbardziej zdegradowanych obszarów, a w konsekwencji całych miast. Działania rewitalizacyjne mają wpłynąć na poprawę ich kondycji i atrakcyjności.

\section{Przemiany gospodarki miast i bazy ekonomicznej - charakterystyka zjawiska}

W dobie współczesnych, szybkich przemian społeczno-ekonomicznych duże znaczenie ma zdolność miast do dostosowania się zmieniających się uwarunkowań i zaspokajania potrzeb mieszkańców. Dywersyfikacja ich struktury gospodarczej jest w tym przypadku bardzo korzystnym zjawiskiem. Jej istotne znaczenie podkreśla się zwłaszcza wtedy, kiedy przyczynia się do tworzenia elastycznych struktur gospodarczych, które zdolne są do wchłaniania innowacji, rozwoju opłacalnych dziedzin produkcji oraz ważne, gdy przyczynia się do tworzenia elastycznych i szybko dostosowujących się struktur gospodarczych do zmieniających się warunków na rynkach lokalnych, regionalnych, krajowych i międzynarodowych ${ }^{2}$. W literaturze przedmiotu wskazuje się wiele korzyści wynikających z dywersyfikacji struktury gospodarczej miast, ponieważ gospodarka o zróżnicowanej strukturze jest bardziej odporna na wahania koniunkturalne. Ma także większe zdolności adaptacyjne, które potrzebne są w okresie przekształceń strukturalnych. Ponadto w wyniku dywersyfikacji działalności gospodarczych powstaje gospodarka o nowoczesnej strukturze, która tworzy podstawę do dalszego rozwoju przedsiębiorstw kreatywnych, ludności oraz kreatywności administracji, co przyczynia się do wzmacniania konkurencyjności miast.

$\mathrm{Z}$ kolei obserwowane zmiany w strukturze zatrudnienia, które są cechą współczesnego rozwoju społeczno-gospodarczego dotyczą m.in. wzrostu udziału

${ }^{1}$ A. Harańczyk, Miasta polskie w procesie globalizacji gospodarki, Wydawnictwo Naukowe PWN, Warszawa 1998.

${ }^{2}$ R. Domański, Geografia ekonomiczna. Ujęcie dynamiczne, Wydawnictwo PWN, Warszawa 2006, s. 232-233. 
zatrudnionych w takich dziedzinach, jak: zarządzanie, logistka, marketing, nauka i badania, projektowanie produktów i wysokiego przetwórstwa, handlu detalicznego, doradztwa prawnego i ekonomicznego, administracji publicznej, finansów i ubezpieczeń, dystrybucji, hotelarstwa i gastronomii. Ponadto można wskazać także zmiany o szczególnym znaczeniu dla gospodarek miejskich. Są nimi: rozwój sektora małych i średnich przedsiębiorstw (MŚP) oraz pojawienie się wielkich korporacji ponadnarodowych. W latach 80., kiedy w wielu krajach rozwiniętych następował intensywny rozwój małych i średnich firm zwrócono uwagę, że w sektorze małej i średniej przedsiębiorczości tworzy się więcej miejsc pracy niż w przedsiębiorstwach dużych. Zwrócono także uwagę na zróżnicowania międzyregionalne w rozwoju MŚP. Sektor MŚP ma jednak kluczowe znaczenie dla gospodarki miejskiej, gdyż jest mniej podatny na zmiany koniunkturalne w gospodarce. Wraz ze zmianami w strukturze zatrudnienia następują zmiany w przestrzennej strukturze miast ${ }^{3}$.

Ponadto rozwój ekonomiczny miasta jest efektem relacji zachodzących pomiędzy strukturą zawodową mieszkańców i charakterem ich pracy a otoczeniem. Zgodnie z założeniami teorii bazy ekonomicznej miasto jest systemem składającym się z dwóch wzajemnie na siebie oddziałujących elementów. Pierwszy z nich tworzą działalności gospodarcze realizowane na rzecz odbiorców spoza miasta (dlatego nazywane egzogenicznymi lub eksportowymi). Sektor ten realizuje wszystkie rodzaje działalności wykonywane w mieście, służące zaspokajaniu potrzeb nie tylko miasta, ale również obszarów zewnętrznych. Druga grupa (endogeniczna) to aktywności obsługujące rynek lokalny - mieszkańców i firmy z miasta. Sektor ten realizuje funkcje endogeniczne (zwane także funkcjami obsługi), czyli działy gospodarki służące zaspokojeniu potrzeb wyłącznie miejscowej ludności, rozwijające się, aby obsługiwać sektor działalności egzogenicznych ${ }^{4}$.

Uważa się, że o powstaniu i wzroście gospodarczym miasta decyduje przede wszystkim sektor egzogeniczny (oparty o popyt zewnętrzny), czasami nazywany podstawowym lub miastotwórczym. Impulsy, które generuje rozwój sektora egzogenicznego wpływają z kolei na wzrost sektora endogenicznego poprzez tzw. efekty mnożnikowe, tj. w wyniku wzrostu lokalnego zapotrzebowania na produkty i usługi. Koncepcja bazy ekonomicznej pozwala identyfikować sektory gospodarki w największym stopniu decydujące o sile gospodarki miasta. Pozwala także na określenie jego specjalizacji gospodarczej.

Miasto w tym przypadku rozpatrywane jest jako całościowy układ społeczny mieszkańców, którzy trudnią się wykonywaniem różnych zawodów, co powoduje, iż każda z grup odgrywa odmienną rolę (funkcję) w społeczności, jak

${ }^{3}$ R. Domański, Geografia ekonomiczna..., s. 243-245.

${ }^{4}$ M.E. Sokołowicz, J. Zasina, Ekonomia miasta, [w:] A. Nowakowska (red.), EkoMiasto\# Gospodarka. Zrównoważony, inteligentny i partycypacyjny rozwój miasta, Wydawnictwo Uniwersytetu Łódzkiego, Łódź 2016, s. 43-63. 
i w stosunku do świata zewnętrznego. W teorii bazy ekonomicznej podkreśla się decydującą rolę grupy mieszkańców i ich znaczenie w mechanizmach rozwoju miast. Dzięki ich działalności i zdolnościom przyciągane są środki ekonomiczne (pieniężne). Są to głównie grupy prowadzące działalność egzogeniczną w mieście, jednak ich praca nie byłaby możliwa bez udziału innych grup (endogenicznych), które zapewniają normalną organizację funkcjonowania miasta jako całości ${ }^{5}$.

Teoria bazy ekonomicznej określa związki przyczynowe i relacje zachodzące w procesie rozwoju miast. Sektor egzogeniczny i endogeniczny są ze sobą sprzężone i wzajemnie na siebie oddziałują. Rozwój sektora egzogenicznego inicjuje wzrost w sektorze endogenicznym, uruchamiając tzw. mechanizm mnożnikowy bazy ekonomicznej. Efekty mnożnikowe są jednym z podstawowych mechanizmów w rozwoju lokalnym. Są wyrazem oddziaływania zmian w zakresie działalności gospodarczych na rozwój innych działalności, szczególnie przy pomocy mechanizmów rynkowych. Mnożnik stanowi próbę ilościowego uchwycenia siły oddziaływania jednej zmiany na inną ${ }^{6}$. W myśl założeń teorii bazy ekonomicznej, sukces odnoszą przede wszystkim te miastazdolne do stworzenia silnej bazy ekonomicznej o wysokich lokalnych efektach mnożnikowych.

Miasta o zdywersyfikowanej i nowoczesnej strukturze gospodarczej mają zdecydowanie większe szanse rozwoju we współczesnym, szybko zmieniającym się świecie. Mają także większe zdolności do poprawy swojej pozycji w szerszym przestrzennym systemie gospodarki krajowej i międzynarodowej. Stąd też niezwykle istotnym procesem $\mathrm{w}$ przypadku miast poprzemysłowych jest dywersyfikacja struktury gospodarczej i rozwój działalności o charakterze egzogenicznym, a specyficzne struktury organizacyjne każdej społeczności lokalnej określają jej zdolności przystosowania się do zmian zewnętrznych przez tworzenie nowych niezależnych firm?

\section{Przemiany struktury funkcjonalnej i bazy ekonomicznej polskich miast po 1989 roku}

Strukturalne przekształcenia miast dokonują się pod wpływem nagłego i silnego szoku lub pod wpływem powolnych zmian o mniejszym nasileniu. Jednak należy podkreślić, że przekształcenia dokonujące się w przypadku

${ }^{5}$ W. Sombart, za: A. Suliborski, Funkcje miast, [w:] S. Liszewski (red.), Geografia urbanistyczna, Wydawnictwo Uniwersytetu Łódzkiego, Łódź 2008.

${ }^{6}$ B. Domański, K. Gwosdz, Efekty mnożnikowe w rozwoju lokalnym i regionalnym, [w:] J.J. Parysek, T. Stryjakiewicz (red.), Region społeczno-ekonomiczny i rozwój regionalny, Bogucki Wydawnictwo Naukowe, Poznań 2008, s. 215.

${ }^{7}$ E. Boryczka, Procesy rewitalizacji i ich konsekwencje dla przeksztatceń bazy ekonomicznej miasta. Przykład miast poprzemystowych, rozprawa doktorska, maszynopis. 
terapii szokowej nie oznaczają całkowitego zerwania z przeszłością. Również tutaj zmienność współwystępuje z kontynuacją ${ }^{8}$. Zmiany, jakie zaszły w Polsce od 1989 r. w związku przejściem od ustroju socjalistycznego do demokracji, zapoczątkowały przekształcenia pierwszego typu. Nowe warunki gospodarowania i związane z nimi nowe zasady zarządzania jednostkami terytorialnymi spowodowały istotne przemiany w strukturze funkcjonalnej miast. Przekształcenia zachodzące w gospodarce i sferze społecznej również wpłynęły na gospodarkę polskich miast. W krótkim czasie zmieniła się struktura działalności nie tylko przedsiębiorstw państwowych, ale także budżetów jednostek samorządów terytorialnych. Zaczęły się pojawiać przedsiębiorstwa w szybko rozwijającym się sektorze prywatnym. Zmianie uległa baza ekonomiczna w przypadku relacji między rolą funkcji produkcyjnych i funkcją usługowych, ale również w proporcjach funkcji endogenicznych i egzogenicznych w gospodarce miast ${ }^{9}$.

Powojenny model gospodarczy Polski związany z gospodarką centralnie planowaną kształtował strukturę funkcjonalną miast. W okresie powojennym, aż do połowy lat osiemdziesiątych, występowała bardzo silna zależność rozwoju i powstawania miast w Polsce od przemysłu i wzrostu zatrudnienia w sektorze przemysłowym. Cechą charakterystyczną tego modelu gospodarczego był niezwykle ekstensywny rozwój przemysłu oraz dynamiczny wzrost zatrudnienia. Intensywna migracja ludności ze wsi do miast spowodowana była nowo powstającymi zakładami przemysłowymi w obszarach miejskich. Napływ ludności do miast z kolei powodował konieczność rozwoju budownictwa, co skutkowało wzrostem zatrudnienia w sektorze budownictwa. Te dwa rodzaje działalności dominowały więc w strukturze zatrudnienia. Stąd też w latach siedemdziesiątych i osiemdziesiątych widoczny był decydujący udział sektora II (przemysł i budownictwo) w gospodarce większości polskich miast. Sytuacja ta była silnie związana z industrializacją kraju oraz z niskim tempem rozwoju sektora usług.

W okresie realnego socjalizmu lokalizacja państwowych zakładów przemysłowych była jednym $\mathrm{z}$ instrumentów podnoszenia poziomu gospodarczego miast i regionów słabo rozwiniętych. Stanowiła przy tym ważny czynnik powstawania i rozwoju miast. Słabo rozwijały się miasta małe, w których nie dokonywano inwestycji przemysłowych. To przemysł jako główna funkcja miastotwórcza, która daje podstawę istnienia i funkcjonowania miast, traktowany był również jako główny czynnik przyspieszenia rozwoju gospodarczego Polski.

Zmiany ustroju politycznego i gospodarczego w Polsce po 1989 r. wymusiły w miastach konieczność przystosowania się do nowych warunków. W trudnej sytuacji znalazły się miasta charakteryzujące się przewagą tradycyjnych gałęzi przemysłu, w tym szczególnie miasta o silnej dominacji jednej działalności ${ }^{10}$.

${ }^{8}$ R. Domański, Miasto innowacyjne, Wydawnictwo Naukowe PWN, Warszawa 2000, s. 25.

9 J. Słodczyk, Przestrzeń miasta i jej przeobrażenia, Uniwersytet Opolski, Opole 2003, s. 82.

${ }^{10}$ J. Słodczyk, Przestrzeń miasta..., s. 83. 
Po pierwszej fazie przekształceń struktury gospodarczej miast po $1989 \mathrm{r}$. i adaptacji do nowych warunków ustrojowych nastąpił spadek produkcji przemysłów tradycyjnych oraz przyspieszony rozwój nowej organizacji przestrzeni przemysłowej, charakterystyczny dla postfordyzmu. W tym przypadku charakterystyczne było zróżnicowanie spadku produkcji w wybranych przemysłach tradycyjnych, rozproszony rozwój przedsiębiorstw w niektórych zmodernizowanych przemysłach tradycyjnych oraz zróżnicowanie pod względem korzyści komparatywnych nagromadzonych w procesie rozwoju. Korzyści te związane były z jakością infrastruktury technicznej, zasobami wysoko wykwalifikowanej siły roboczej oraz jakością środowiska.

Transformacja gospodarcza i społeczna polskich miast znajduje wyraz $\mathrm{w}$ stopniowej zmianie typów funkcjonalnych miast. Zmiany związane $\mathrm{z}$ transformacją ustrojową po 1989 r. wpłynęły na zmiany funkcji wielu polskich miast, nie tylko pod względem liczby pracujących w poszczególnych sektorach, ale także dominacji działalności gospodarczej miasta oraz wielkości PKB wytwarzanego na jego terenie ${ }^{11}$.

Od 1989 r. widoczna jest dezindustrializacja miast i rośnie znaczenie sektora usługowego. Zmieniła się struktura pracujących z wyraźnym procesem jej serwicyzacji. Nastąpił znaczny przyrost udziału pracujących w sektorze usług (serwicyzacja pracy, zatrudnienia). Nastąpiło także zwiększenie roli tego sektora w tworzeniu PKB (serwicyzacja wytwarzania) oraz nastąpił wzrost konsumpcji usług oraz zwiększył się jej udział w całościowej ogólnej konsumpcji gospodarstw domowych (serwicyzacja konsumpcji) ${ }^{12}$. Intensywność procesu serwicyzacji gospodarki miast, regionów i poszczególnych miast jest cechą wspólną dla krajów Europy Środkowej i Wschodniej. Zmiany w strukturze pracujących i typach funkcjonalnych miast w Polsce są odzwierciedleniem rozwoju gospodarczego i przemian strukturalnych i modernizacyjnych, które sprzyjają rozwojowi sektora usługowego. Transformacja ustrojowa przyspieszyła zmiany ośrodków miejskich z przemysłowych w kierunku usługowym. Proces ten jednak nie jest jeszcze zakończony. Zmniejszanie się miejsc pracy w sektorze produkcyjnym będzie

${ }^{11}$ W 1973 r. z punktu widzenia funkcji dominującej w miastach przeważały trzy typy miast: miasta o funkcji usługowo-przemysłowej, przemysłowo-usługowej oraz przemysłowe. Stanowiły 67,4\% miast Polski i koncentrowały 93\% ludności miejskiej. Natomiast w 2003 r. połowa miast $(49,3 \%)$ miała już charakter usługowy, a 24,3\% usługowo-przemysłowy. W tym okresie ponad 7-krotnie wzrosła liczba miast usługowych (U), wzrósł także udział miast usługowo-przemysłowych (UP) z 20,1 do 24,3\%, a miasta rolnicze, rolniczo-usługowe, przemysłowo-rolnicze i bez funkcjonalnej dominacji zniknęły z mapy. Zachodzące zmiany doprowadziły także do zmarginalizowania funkcji rolniczej. Stwierdzono również, że wraz ze wzrostem wielkości miasta maleje udział funkcji produkcyjnych. M. Jerczyński, Zagadnienia specjalizacji bazy ekonomicznej większych miast w Polsce, [w:] M. Jerczyński, L.F. Chaves, Z. Siemek (red.), Studia nad struktura funkcjonalna miast, Prace Geograficzne nr 97, PAN IG, Wrocław-Warszawa-Kraków-Gdańsk, 1973; D. Szymańska, Geografia osadnictwa, Wydawnictwo PWN, Warszawa 2009, s. 246.

${ }_{12}$ D. Szymańska, Geografia osadnictwa..., s. 247-248. 
postępować, ograniczając rolę przemysłu jako podstawy egzystencji szczególnie małych i średnich ośrodków miejskich. Współcześnie proces rozwoju przemysłu musi wiązać się ze wzrostem wydajności pracy. Ograniczanie miejsc pracy w tym sektorze, w myśl teorii bazy ekonomicznej, oznacza ograniczenie sektora egzogenicznego.

Władze jednostek samorządu terytorialnego niejednokrotnie upatrują możliwość odwrócenia tych negatywnych tendencji w małych i średnich miastach poprzez uruchomienie nowych, dużych inwestycji produkcyjnych, które staną się podstawą zatrudnienia, rozwoju bazy ekonomicznej oraz wywołają dynamiczny rozwój funkcji usługowych. Niestety, takie sytuacje zdarzają sięrzadko, a większość tego typu inwestycji wiąże się z małym zatrudnieniem w nowoczesnych i zmechanizowanych przedsiębiorstwach. Stąd też podkreśla się konieczność stosowania różnych narzędzi prowadzących do rozwoju firm z sektora MŚP w średnich i małych miastach, które będą się rozwijać w dziedzinach o charakterze egzogenicznym oraz produkować i świadczyć usługi na rynek ponadlokalny. Jednak, jak pokazuje szereg badań, rozwój przedsiębiorstw z sektora MŚP napotyka trudności z przyczyn wewnętrznych (w tym mentalnych społeczności lokalnej) i przede wszystkim ze strony uwarunkowań zewnętrznych ${ }^{13}$.

Przemiany struktury funkcjonalnej i bazy ekonomicznej miasta wywołują zmiany w jego strukturze przestrzennej, a jedną z głównych cech wyróżniających przestrzeń miejską $\mathrm{w}$ ogólnej przestrzeni geograficznej jest wielofunkcyjność ${ }^{14}$. Poszczególne działalności gospodarcze, a także społeczne, wykonywane w mieście potrzebują terenu i jego odpowiedniego zagospodarowania. Funkcje mają zróżnicowane wymagania, związane z cechami zagospodarowania i lokalizacją. Podmioty gospodarcze prowadzące działalność na terenie miasta poszukują takich terenów, które pozwolą im najefektywniej realizować swoje cele. Zatem w wyniku zajmowania działek pod poszczególne typy działalności, zgodnie z ich preferencjami, w mieście tworzy się określona struktura użytkowania terenu stanowiąca odzwierciedlenie struktury funkcjonalnej. Tkanka miejska wypełniana jest różnorodną działalnością charakterystyczną dla skupisk miejskich. Wyrazem funkcji realizowanych w mieście są formy, struktury i typy użytkowania terenu. Funkcja wypełnia określoną część przestrzeni w sposób dla siebie najdogodniejszy i charakterystyczny.

Jednak współzależność między funkcjami i strukturą przestrzenną nie jest jednoznaczna. W obrębie tych samych układów przestrzennych mogą rozwijać się różne funkcje, a także takie same funkcje mogą rozwijać się w różnych strukturach przestrzennych. Funkcje, które rozwijają się często, nie mieszcząc się w istniejących strukturach przestrzennych, rozsadzają je, tworząc tym samym nowe struktury

13 J. Słodczyk, Przestrzeń miasta..., s. 85-87.

${ }^{14}$ S. Liszewski, Formy i struktury przestrzenne wielkich skupisk miejskich, [w:] S. Liszewski (red.), Geografia urbanistyczna, Wydawnictwo Uniwersytetu Łódzkiego, Łódź 2008, s. 199. 
przestrzenne. Podkreślić należy, że sfera przestrzenna miasta, w tym m.in. zagospodarowanie w sposób opóźniony reaguje na zamiany realizowanych działalności mieszkańców i użytkowników miasta (funkcji), czyli na zmiany elementów niematerialnych, które następują stosunkowo szybko ${ }^{15}$. Charakter funkcjonalny miasta znajduje swoje odzwierciedlenie nie tylko w strukturze zawodowej ludności, ale także w urządzeniach trwałych oraz formach użytkowania ziemi ${ }^{16}$.

\section{Proces rewitalizacji miasta a ich baza ekonomiczna}

Władze samorządowe znajdujące się w trudnej sytuacji i borykające się ze złożonymi problemami ekonomicznymi i społecznymi w miastach, w tym w miastach poprzemysłowych, od dawna upatrują możliwości wyprowadzenia ich ze stanu kryzysowego poprzez działania rewitalizacyjne. Korzystne dla władz samorządowych miast wydają się działania rewitalizacyjne finansowane lub współfinansowane ze środków Unii Europejskiej, jednak widoczne są silne rozbieżności w definiowaniu i w podejściu do zagadnień rewitalizacji. Również uwarunkowania polityczne i finansowe oraz inne czynniki negatywnie wpłynęły na podejmowane działania niby „rewitalizacyjne”.

Rewitalizacja zajmuje uwagę badaczy od dłuższego czasu. Temat rewitalizacji poruszany jest $\mathrm{w}$ pracach geografów, socjologów, planistów przestrzennych, architektów i urbanistów i ekonomistów.

Rewitalizacja rozumiana jest jako skoordynowany proces działań prowadzony przez władzę samorządową, społeczność lokalną oraz przez innych uczestników tego procesu. Jest elementem polityki rozwoju lokalnego i ma przeciwdziałać degradacji przestrzeni zurbanizowanej, występującym tam licznym zjawiskom kryzysowym (społecznym i gospodarczym), pobudzać rozwój społeczno-gospodarczy i wprowadzić zmiany jakościowe. Rozwój miast czy też wybranych obszarów dokonuje się poprzez wzrost aktywności społecznej i gospodarczej, poprawę jakości środowiska zamieszkania oraz równoczesną ochronę dziedzictwa narodowego, przy jednoczesnym zachowaniu zasad zrównoważonego rozwoju ${ }^{17}$. Rewitalizacja, z założenia, jest połączeniem działań o charakterze społecznym, gospodarczych i przestrzennym, a także środowiskowym w zdegradowanych przestrzeniach miast ${ }^{18}$.

15 R. Domański, Geografia ekonomiczna..., s. 106.

${ }^{16}$ K. Dziewoński, Zagadnienie typologii morfologicznej miast w Polsce. Przeglad Geograficzny, t. 33, z. 4, 1962 s. 443.

${ }_{17}$ Z. Ziobrowski, M. Bryx (red.), Finansowanie i gospodarka nieruchomościami w procesach rewitalizacji, Instytut Rozwoju Miast, Kraków 2009, s. 7.

${ }^{18}$ E. Boryczka, Rewitalizacja miast, [w:] Z. Przygodzki (red.), EkoMiasto\#Zarzadzanie. Zrównoważony, inteligentny i partycypacyjny rozwój miasta, Wydawnictwo Uniwersytetu Łódzkiego, Łódź 2016, s. 167-189. 
Rewitalizacja jest procesem kompleksowym uruchamianym dla uzyskania zmian prowadzących do ożywienia gospodarczego, społecznego i kulturalnego zdegradowanych fragmentów lub całych miast ${ }^{19}$. Polega na wprowadzeniu do takiego obszaru innych niż tradycyjnie występujące funkcje z jednoczesnym przekształceniem obecnej formy przestrzennej przez wznoszenie nowej zabudowy oraz modernizację i adaptację części istniejących obiektów do nowych potrzeb ${ }^{20}$. Rewitalizacja jest nową fazą rozwoju miasta. Jej zainicjowanie jest niezbędne w momencie, gdy dotychczasowe działania podtrzymujące i konserwujące tkankę miasta nie wystarczają ${ }^{21}$. Podejmowane działania ukierunkowane są na ochronę i odnowę istniejących wartości kulturowych przestrzeni miejskiej, promowanie i inicjowanie aktywności wzmacniających bazę ekonomiczną miasta, a także aktywizację społeczną i gospodarczą lokalnych mieszkańców. Rewitalizacja ma poprawić warunki życia i pracy w mieście, przywrócić ład przestrzenny, spowodować ożywienie gospodarcze danego terenu. W procesie rewitalizacji w wyniku skoordynowanych działań mających na celu przekształcenia struktury funkcjonalnej i przestrzennej zdegradowanych obszarów miast następują przekształcenia bazy ekonomicznej miasta, podstawę jego rozwoju ${ }^{22}$. Rewitalizacja jest silnie skorelowana z bazą ekonomiczną miasta. W wyniku działań rewitalizacyjnych wzmacniany jest sektor działalności egzogenicznych (tzw. miastotwórczych), który będzie sprzyjał rozwojowi działalności endogenicznych.

Rewitalizacja obszarów miejskich ma charakter niezwykle złożony i niepowtarzalny podobnie jak miasta, których dotyczy, gdyż są to bardzo indywidualne systemy, na które ma wpływ wiele różnorodnych czynników ${ }^{23}$. Jest to proces złożony, a wszelkie analizy dotyczące planowanych przekształceń powinny nawiązywać do specyfiki danego obszaru, miejsca w hierarchii rozwoju, w jakim się znajduje oraz drogi rozwoju, jaką ma za sobą. Jest to niezwykle istotne, szczególnie gdy planuje się działania rewitalizacyjne w oparciu o doświadczenia z innych miast, czy krajów ${ }^{24}$.

19 J.J. Parysek, Miasta polskie na przełomie XX i XXI wieku. Rozwój i przekształcenia strukturalne, Bogucki Wydawnictwo Naukowe, Poznań 2005.

${ }^{20}$ S. Kaczmarek, Rewitalizacja terenów poprzemysłowych. Nowy wymiar w rozwoju miast, Wydawnictwo Uniwersytetu Łódzkiego, Łódź 2001, s. 22-23 oraz S. Kaczmarek, Rewitalizacja jako proces przekształcania terenów przemysłowych w miastach, [w:] Zeszyt KIN, Zwarta przebudowa polskich miast? Zarzadzanie rozwojem miasta poprzez strategiczne gospodarowanie terenami, Fundacja Krakowski Instytut Nieruchomości, Kraków 2000, s. 43-45.

${ }^{21}$ S. Cunningham, The Restoration economy, Berreyy-Koehler Publishers, Inc, San Francisco 2002. Autor wskazuje trzy główne etapy życia miasta: (1) pierwotny rozwój, (2) utrzymanie i konserwację, (3) rewitalizację.

${ }^{22}$ E. Boryczka, Rewitalizacja miast..., s. 167-189.

${ }^{23}$ T. Biliński, Systemowe ujęcie programu rewitalizacji obszaru miejskiego, [w:] Renowacja budynków i modernizacja obszarów zabudowanych. Tom 2, Wydawnictwo Uniwersytetu Zielonogórskiego, Zielona Góra 2006, s. 29.

${ }^{24}$ F. Tomczak, Rewitalizacja a rozwój gospodarczy, [w:] H. Godlewska-Majkowska, K. Kuciński (red.), Edukacja jako czynnik rozwoju regionów rewitalizowanych, Szkoła Główna Handlowa w Warszawie, Warszawa 2006, s. 12. 
Rewitalizacja jest procesem wyjątkowo skomplikowanym i wymaga odpowiedniego czasu na realizację. Twierdzi się przy tym, że pierwsze głębsze efekty przekształceń widoczne są po ok. 5 latach od rozpoczęcia realizacji, natomiast sam proces nie powinien trwać dłużej niż 25-30 lat ${ }^{25}$. Z tego względu rozpatruje się ją w odniesieniu do całościowej polityki rozwoju miasta, której cele działań są mocno zróżnicowane ${ }^{26}$. Istotna jest więc zmiana struktury funkcjonalnej miast poprzemysłowych, które po 1989 r. borykają się z poważnymi problemami gospodarczymi i społecznymi.

\section{Podsumowanie i wnioski}

Rewitalizacja wydaje się szansą na dywersyfikację gospodarki miast poprzemysłowych i rozwój działalności o charakterze egzogenicznym, decydujących o rozwoju, kondycji oraz atrakcyjności miasta. Proces ten powinien zatem dostosować miasta do zmieniających się potrzeb mieszkańców, wzmocnić ich możliwości ekonomiczne, sprawić, że lepiej będą reagowały na zmiany w otoczeniu i będą mniej podatne na wpływy zewnętrzne. Działania rewitalizacyjne podejmowane są w Polsce już od wielu lat. Zapoczątkowano je już w latach 90. Analiza skutków przedsięwzięć rewitalizacyjnych, niejednokrotnie pochłaniających miliardy złotych i trwających wiele lat, pozwala na wskazanie pewnej specyfiki tego procesu w Polsce.

Wnioski z przeprowadzonych analiz i obserwacji wskazują, że w wielu miastach w Polsce po transformacji ustrojowej na pierwszy plan działań wysuwano odnowę istniejących form architektoniczno-urbanistycznych, w których nie było już miejsca dla prowadzonych dotychczas działalności, a także nie zapewniono dostatecznych impulsów do rozwoju nowych rodzajów działalności ${ }^{27}$. Działania rewitalizacyjne, skoncentrowane na typowo architektoniczno-urbanistycznych aspektach, z reguły nie przynosiły oczekiwanych efektów i nie miały wiele wspólnego z pobudzaniem aktywności gospodarczej zdegradowanych obszarów.

Dodatkowo w Polsce silna koncentracja działań i środków finansowych związanych z dostępnością funduszy europejskich na wybrane typy projektów sprawiła, że rewitalizacja stała się nadużywanym i nierozumianym słowem służącym do pozyskiwania przez samorządy zewnętrznych środków finansowych, głównie na działania infrastrukturalne oraz związane z ochroną i konserwacją zabytków.

${ }^{25}$ K. Skalski, Problemy rewitalizacji, [w:] Gospodarka przestrzenna gmin. Poradnik. Tom III, Instytut Gospodarki Przestrzennej i Komunalnej Oddział w Krakowie, Kraków 1998.

${ }^{26}$ T. Biliński, Studia programowe i metody realizacji przedsięwzięć rewitalizacyjnych, ,sprawy mieszkaniowe”, Instytut Gospodarki Mieszkaniowej, z. 1-2, Kraków 2001.

${ }^{27}$ R. Domański, Geografia ekonomiczna..., s. 250-251. 
Ponadto rewitalizacja, podobnie jak efektywna i skuteczna polityka rozwoju, wymaga silnego przywództwa politycznego, a także aktywnego udziału społeczności lokalnej, w tym m.in. promowania współpracy ze strony władz samorządowych i wspólnego rozwiązywania problemów lokalnych. Proces rewitalizacji polskich miast przez wiele lat traktowano jako jedno z zadań publicznych władz samorządowych, których rola koncentruje się nie na koordynacji, inicjowaniu, ale przede wszystkim realizowaniu działań rewitalizacyjnych. W Polsce wciąż brakuje podejścia komercyjnego i biznesowego do zagadnień rewitalizacji. Brakuje działań skierowanych na pobudzanie lokalnej przedsiębiorczości i dywersyfikację gospodarki miasta. Działania rewitalizacyjne realizowane głównie przez sektor publiczny skoncentrowane były na sferze przestrzennej i zdeterminowane własnością nieruchomości, a bez koordynacji i współpracy z innymi podmiotami, szczególnie z podmiotami z sektora prywatnego nie powodowały zaangażowania środków finansowych tego sektora. Jak pokazują wyniki badań największe pozytywne zmiany w wyniku działań rewitalizacyjnych w polskich miastach obserwuje się w estetyce przestrzeni publicznej centrum miasta oraz w jego wizerun$\mathrm{ku}$. W ostatnich latach nastąpiła również znaczna poprawa stanu infrastruktury technicznej. Działania rewitalizacyjne w niewielkim stopniu wpłynęły na bezpieczeństwo i porządek publiczny oraz na zainteresowanie mieszkańców i klientów tymi obszarami miasta oraz na rozwój oferty handlowo-usługowej. Ponadto w polskich miastach podmioty sektora publicznego wskazują, że podejmowane działania rewitalizacyjne w najmniejszym stopniu nie wpłynęły na aktywność przedsiębiorstw oraz eliminację problemów społecznych ${ }^{28}$.

Warto również zaznaczyć, że przez wiele lat w Polsce proces rewitalizacji miast odbywał się bez uregulowań prawnych i systemowych obejmujących m.in. realizację interesu publicznego $\mathrm{w}$ zakresie rewitalizacji, ograniczania prawa własności na rzecz interesu publicznego, obowiązkowej partycypacji społecznej tak, jak jest to rozwiązane, np. w wielu krajach Europy Zachodniej (m.in.: Francja, Niemcy). W Polsce przez wiele lat nie było w zasadzie krajowych przepisów prawnych, na których podstawie jednostki samorządu terytorialnego mogłyby przygotować i sprawnie przeprowadzić działania rewitalizacyjne, choć takie próby podejmowano ${ }^{29}$.

Sytuację w Polsce zmieniają jednak zapisy nowej ustawy o rewitalizacji z 2015 r. oraz inne uwarunkowania prawne i organizacyjne procesów rewitalizacji związane z nową perspektywą finansową UE na lata 2014-2020 Jednak zanim w miastach pojawią się efekty działań rewitalizacyjnych o charakterze gospodarczym, wzmacniające i rozwijające ich bazę ekonomiczną, upłynie wiele lat.

${ }^{28}$ Szerzej wyniki badań prezentowane są w artykule: E. Boryczka, Cooperation between public, private and social sectors in the process of revitalization of the city centres in Poland, Prace Naukowe Uniwersytetu Ekonomicznego we Wrocławiu, Wrocław 2015.

${ }^{29}$ E. Boryczka, Rewitalizacja miast..., s. 167-189. 
Charakter procesu rewitalizacji ze względu na przedmiot działań oraz na podmioty współuczestniczące wymaga kompleksowych podejścia i współpracy między różnymi podmiotami, stąd też rewitalizacja miast w Polsce jest procesem ograniczonym, głównie do działań zwłaszcza gospodarczych i społecznych.

\section{Bibliografia}

Biliński T., Studia programowe i metody realizacji przedsięwzięć rewitalizacyjnych, ,, sprawy mieszkaniowe”, Instytut Gospodarki Mieszkaniowej, z 1-2, Kraków 2001.

Biliński T., Systemowe ujęcie programu rewitalizacji obszaru miejskiego, [w:] Renowacja budynków i modernizacja obszarów zabudowanych. Tom 2, Wydawnictwo Uniwersytetu Zielonogórskiego, Zielona Góra 2006, s. 29.

Boryczka E., Rewitalizacja miast, [w:] Przygodzki Z. (red.), EkoMiasto\#Zarzadzanie. Zrównoważony, inteligentny i partycypacyjny rozwój miasta, Wydawnictwo Uniwersytetu Łódzkiego, Łódź 2016.

Boryczka E., Cooperation between public, private and social sectors in the process of revitalization of the city centres in Poland, Prace Naukowe Uniwersytetu Ekonomicznego we Wrocławiu, Wrocław 2015.

Boryczka E., Procesy rewitalizacji i ich konsekwencje dla przekształceń bazy ekonomicznej miasta. Przykład miast poprzemysłowych, rozprawa doktorska, maszynopis.

Cunningham S., The Restoration economy, Berreyy-Koehler Publishers, Inc, San Framcisco 2002.

Domański B., Gwosdz K., Efekty mnożnikowe w rozwoju lokalnym i regionalnym, [w:] Parysek J.J., Stryjakiewicz T. (red.), Region społeczno-ekonomiczny i rozwój regionalny, Bogucki Wydawnictwo Naukowe, Poznań 2008, s. 215.

Domański R., Geografia ekonomiczna. Ujęcie dynamiczne, Wydawnictwo PWN, Warszawa 2006, s. 232-233.

Domański R., Miasto innowacyjne, Wydawnictwo Naukowe PWN, Warszawa 2000, s. 25.

Dziewoński K., Zagadnienie typologii morfologicznej miast w Polsce, „Przegląd Urbanistyczny”, $\mathrm{t}$. 33, z. 4, 1962, s. 443.

Harańczyk A., Miasta polskie w procesie globalizacji gospodarki, Wydawnictwo Naukowe PWN, Warszawa 1998.

Jerczyński M., Zagadnienia specjalizacji bazy ekonomicznej większych miast w Polsce, [w:] Jerczyński M., Chaves L.F., Siemek Z. (red.), Studia nad struktura funkcjonalna miast, ,Prace Geograficzne" nr 97, PAN IG, Wrocław-Warszawa-Kraków-Gdańsk, 1973.

Kaczmarek S., Rewitalizacja terenów poprzemysłowych. Nowy wymiar w rozwoju miast, Wydawnictwo Uniwersytetu Łódzkiego, Łódź 2001, s. 2223.

Liszewski S., Formy i struktury przestrzenne wielkich skupisk miejskich, [w:] Liszewski S. (red.), Geografia urbanistyczna, Wydawnictwo Uniwersytetu Łódzkiego, Łódź 2008, s. 199.

Parysek J.J., Miasta polskie na przełomie XX i XXI wieku. Rozwój i przekształcenia strukturalne, Bogucki Wydawnictwo Naukowe, Poznań 2005.

Skalski K., Problemy rewitalizacji, [w:] Gospodarka przestrzenna gmin. Poradnik Tom III, Instytut Gospodarki Przestrzennej i Komunalnej Oddział w Krakowie, Kraków 1998.

Słodczyk J., Przestrzeń miasta i jej przeobrażenia, Uniwersytet Opolski, Opole 2003, s. 82.

Sokołowicz M.E., Zasina J., Ekonomia miasta, [w:] Nowakowska A. (red.), EkoMiasto\#Gospodarka. Zrównoważony, inteligentny $i$ partycypacyjny rozwój miasta, Wydawnictwo Uniwersytetu Łódzkiego, Łódź 2016, s. 4363. 
Suliborski A., Funkcje miast, [w:] Liszewski S. (red.), Geografia urbanistyczna, Wydawnictwo Uniwersytetu Łódzkiego, Łódź 2008.

Szymańska D., Geografia osadnictwa, Wydawnictwo PWN, Warszawa 2009.

Tomczak F., Rewitalizacja a rozwój gospodarczy, [w:] Godlewska-Majkowska H., Kuciński K. (red.), Edukacja jako czynnik rozwoju regionów rewitalizowanych, Szkoła Główna Handlowa w Warszawie, Warszawa 2006, s. 12.

Ziobrowski Z., Bryx M. (red.), Finansowanie i gospodarka nieruchomościami w procesach rewitalizacji, Instytut Rozwoju Miast, Kraków 2009, s. 7.

\section{Streszczenie}

Polskie miasta ulegają ciągłym przemianom, a w dobie intensywnych przemian społeczno-gospodarczych i politycznych borykają się z wieloma problemami. Wskutek przemian polityczno-gospodarczych po 1989 r. wiele miast poprzemysłowych stanęło przed wyzwaniem dostosowania nie tylko ich przestrzeni do zmieniających się uwarunkowań i potrzeb mieszkańców, ale także przed wyzwaniem dostosowania kompetencji i umiejętności pracowników do zmieniających się wymagań i potrzeb rynku pracy. Problemy bezrobocia, w tym długotrwałego, ubóstwa, marginalizacji społecznej oraz te związane z brakiem aktywności lokalnej społeczności w życiu publicznym powodują trudną sytuację wielu miast poprzemysłowych. Rewitalizacja jako proces naprawczy, wyprowadzający fragmenty lub całe miasta $\mathrm{z}$ sytuacji kryzysowej wydaje się idealnym narzędziem poprawy sytuacji miast poprzemysłowych. Niniejszy artykuł stanowi próbę identyfikacji kluczowych związków przemian gospodarki miast poprzemysłowych, szczególnie ich bazy ekonomicznej i procesu rewitalizacji.

Słowa kluczowe: baza ekonomiczna miast, rewitalizacja, miasta poprzemysłowe Numer klasyfikacji JEL: P25 